Jurnal Info Kesehatan

Vol. 19, No. 1, June 2021, pp. 64-76

P-ISSN 0216-504X, E-ISSN 2620-536X

DOI: 10.31965/infokes.Vol19Iss1.514

Journal homepage:http://jurnal.poltekeskupang.ac.id/index.php/infokes

RESEA R C H

Open Access

\title{
Simultaneous Factors Affecting Toddler Nutritional Status
}

\author{
Yoany M. Vianney Bita Aty ${ }^{1 a^{*}}$, Elisabeth Herwanti ${ }^{1 \mathrm{~b}}$, Rohana Mochsen ${ }^{1 \mathrm{c}}$ \\ ${ }^{1}$ Department of Nursing, Poltekkes Kemenkes Kupang, Kupang, East Nusa Tenggara, \\ Indonesia. \\ a Email address: vivi_aty@yahoo.co.id \\ b Email address: elisabeth_herwanti@yahoo.com \\ c Email address: rohanamochsen@yahoo.com
}

Received: 13 March 2021

Revised: 26 May 2021

Accepted: 27 June 2021

\begin{abstract}
The province with the highest percentage of malnutrition among children aged 0-59 months in 2018 was East Nusa Tenggara. The number of toddlers experiencing malnutrition in the Feapoi Health Center area, Rote Ndao district, fluctuated from 2013 to 2017 ranging from 3-12 cases. In 2020, data on 31 toddlers were malnourished and 7 were malnourished based on body weight divided by age (W/W). Efforts made by the Rote Ndao government to reduce stunting and malnutrition are education, routinely providing Supplementary Feeding (PMT), but the incidence of malnutrition and stunting is still high. The study was conducted to analyze the simultaneous factors that affect the nutritional status of toddlers in the Feapoi Health Center area, Rote Ndao Regency. This type of research is quantitative, the design is case control. The research sample consisted of 38 well-nourished toddlers and 38 undernourished toddlers. The research instrument was a questionnaire and a Healthy Towards Card. Univariate data analysis was descriptive, bivariate analysis used Chi Square with a significant level of $5 \%(\alpha=$ $0.05)$, multivariate with multiple logistic regression. The results showed that the factors that simultaneously affected the nutritional status of toddlers in the Feapoi health center, Rote Ndao district were a history of low birth weight $(\mathrm{p}=0.014$, OR $0.109,95 \% \mathrm{CI}$ : $0.18-0.638)$, and toddlers with exclusive breastfeeding $(\mathrm{p}=0.000$, OR $0.063,95 \% \mathrm{CI}$ $0.18-0.215)$. It is recommended for further research on health promotion efforts for pregnant women to reduce the risk of low birth weight (LBW) and increase exclusive breastfeeding.
\end{abstract}

Keywords: Nutritional Status, Toddlers, Feapoi Health Center.

\footnotetext{
*Corresponding Author:

Yoany M. Vianney Bita Aty

Department of Nursing, Poltekkes Kemenkes Kupang, Kupang, East Nusa Tenggara, Indonesia. Email: vivi_aty@yahoo.com

CThe Author(s) 2021. This article is distributed under the terms of the Creative Commons Attribution 4.0 International License (http://creativecommons.org/licenses/by/4.0/), which permits unrestricted use, distribution, and reproduction in any medium, provided you give appropriate credit to the original author(s) and the source, provide a link to the Creative Commons license, and indicate if changes were made. The Creative Commons Public Domain Dedication waiver (http://creativecommons.org/publicdomain/zero/1.0/) applies to the data made available in this article, unless otherwise stated.
} 


\section{INTRODUCTION}

The problem of malnutrition occurs in almost all economic strata of people in rural and urban areas. This condition is one of the main obstacles affecting the development of Indonesian human resources. Nutritional status is one of the determinants of the quality of human resources, as well as a determinant of success in national development (Kementerian Kesehatan, R. I., 2019).

Malnutrition is nutritional status based on the body weight index for age (W/W) and this is still a problem in Indonesia, including the province of East Nusa Tenggara. The 2018 Basic Health Research stated that the percentage of malnutrition in children aged 0-23 months in Indonesia was 3.8\%, while the percentage of undernourished was $11.4 \%$ (Kementerian Kesehatan, R. I., 2018). It is not much different from the results of the Nutrition Status Monitoring (PSG), that is the percentage of malnutrition in toddlers aged $0-23$ months is $3.8 \%$ and the percentage of malnutrition is $11.4 \%$ (Kementerian Kesehatan, R. I., 2020). The province with the highest percentage of malnutrition and malnutrition in children aged $0-23$ months in 2018 is East Nusa Tenggara, which is 17.7\% (Kementerian Kesehatan, R. I., 2020).

The number of toddlers experiencing malnutrition in the Feapoi Health Center area of Rote Ndao Regency has fluctuated from 2013 to 2017 ranging from 3-12 cases (Dinas Kesehatan Kabupaten Rote Ndao, 2019). In 2020, the number of toddlers at the Feapoi Health Center was 771 people. Toddlers with malnutrition 31 people and 7 toddlers experienced severe malnutrition which was measured based on $\mathrm{BB} / \mathrm{U}$.

The problem of malnutrition and poor nutrition occurs due to several factors, which are nutritional intake and infectious diseases. External factors that cause malnutrition are environmental sanitation, access and utilization of health services, consumption of blood-added tablets, poverty rates, incomplete immunizations, diarrheal diseases, and acute respiratory infections. In addition, unstable political conditions and a slow-growing economy have also contributed to the increase in the problem of malnutrition (Boli, et al., 2018).

Various efforts have been performed by various parties, both government and private to overcome nutritional problems. The Ministry of Health has increased the target for Supplementary Feeding (PMT) for underweight toddlers and pregnant women with Chronic Energy Deficiency (KEK), providing Blood Supplementary Tablets (TTD) for all pregnant women, and young women. Provision of PMT for underweight toddlers, nutrition education efforts to increase exclusive breastfeeding, infant and child feeding (PMBA), and promotion of balanced nutrition guidelines (Kementerian Kesehatan, R. I., 2019).

Efforts to implement balanced nutrition are conducted by means of education and assistance to families on how to prevent and deal with nutritional problems in their family members. Families also need to provide nutritional supplements as recommended by health workers. Nutritional supplements are in accordance with the Regulation of the Minister of Health Number 51 of 2016 concerning Nutritional Supplementation Product Standards, including vitamin A capsules, Blood-Adding Tablets (TTD), supplementary food for pregnant women, toddlers, and school-aged children, complementary foods for breast milk, and multi-vitamin powder and minerals (Kementerian Kesehatan, R. I., 2019). Another effort is the Minister of Health Regulation Number 23 of 2014 concerning Nutrition Improvement Efforts. The activities conducted were weighing regularly, giving exclusive breastfeeding to babies 
from birth to 6 months of age, varied food menus, and consuming iodized salt according to the specified dose.

The Regional Government of East Nusa Tenggara Province (NTT) has made a nutrition policy that is listed in the Regional Medium Term Development Plan (RPJMD) document with a target focus on reducing cases of toddlers malnutrition to $7.64 \%$ and malnutrition to $0.76 \%$ in 2018 as the basis for nutritional development in East Nusa Tenggara Province. There is a Governor's Regulation Number 46 of 2016 concerning Regional Action Plans for the Acceleration of Fulfillment of Food and Nutrition for the Province of East Nusa Tenggara in 2016-2020. The nutrition policy is expected to be able to overcome nutritional problems in East Nusa Tenggara Province. Data shows an increase in nutritional problems, especially underweight and stunting, in 2016 by $28.2 \%$ and $38.7 \%$, respectively, to $28.3 \%$ and $40.3 \%$ in 2017 (Boli, et al., 2018).

Efforts made by the Rote Ndao government to reduce stunting and malnutrition are conducting outreach activities in the community, and the provision of Supplementary Food for undernourished toddlers on a regular basis. The government is committed to prioritizing health services for toddlers. However, the incidence of undernourished toddlers and stunting is still there. It needs to be studied more deeply about the factors that most influence the incidence of malnutrition in Rote Ndao, especially in the Feapoi Health Center area. The objective of this study is to analyze the simultaneous factors that affect the nutritional status of toddlers in the Feapoi Health Center area, Rote Ndao Regency.

\section{RESEARCH METHOD}

The type of research used was quantitative with a case control design. The research was conducted at the Feapoi Health Center, Rote Ndao Regency in January February 2021. The research population was all mothers of toddlers with malnutrition in the working area of the Feapoi Health Center, Rote Ndao Regency. The sampling technique was non-probability sampling with the determination of the total population sample. The number of malnourished toddlers was 38, consisting of 31 undernourished and 7 malnourished. As the control, 38 toddlers with good nutrition were selected. The control sample was determined by the researchers with the criteria of mothers and toddlers living in the working area of the Feapoi Health Center, participating in integrated service post activities and having a Healthy Towards Card (KMS).

The instrument employed was a questionnaire, which contains the characteristics of the respondents, knowledge and actions. Knowledge was measured using a questionnaire with 18 questions. The category of knowledge is good if the score is 1018 and less good with a value of $<10$. The measuring instrument consists of 18 questions. The action category is good with a score of 54-72 and less good if the score is 1-53. The nutritional status of toddlers is measured by using the KMS that the toddler already has. The research questionnaire was adopted from Munthofiah in 2019. From the results of testing for each variable, it was found that knowledge has good internal consistency with each statement item having a total item correlation above 0.20 and Cronbach's Alpha value $>0.60$, that is 0.777 while the behavioral element in this study has good internal consistency with each statement item having a total item correlation above 0.20 and Cronbach's Alpha value of 0.795 (Munthofiah, 2019).

Data collection procedures include obtaining research permits and ethical permits. Ethics certificate was issued by the Kupang Ministry of Health Polytechnic ethics commission. Researchers identified mothers whose babies were underweight through maternal health unit cadres and health workers. After the research sample was obtained 
based on the inclusion criteria, the informed consent was given to parents of toddlers. If the respondent is willing, a questionnaire is distributed to be filled out by the parents of the toddler. Interviews were conducted if the respondents did not understand the questions in the questionnaire. Assessment of the nutritional status of toddlers using data was taken from KMS.

Univariate analysis was employed to describe each independent and dependent variable. Bivariate analysis was performed to examine the relationship between two variables (independent and dependent) at a significant level of 5\% $(\alpha=0.05)$. The type of test was determined based on the data scale and the normality of the data. The results of the study obtained that the distribution of abnormal data so that the tests used were Chi-Square. Multivariable analysis used multivariate test with multiple logistic regression to determine the factors that influence the nutritional status of toddlers simultaneously.

\section{RESULTS AND DISCUSSION}

Table 1. The relationship between maternal characteristics and the nutritional status of toddlers in the working area of the Feapoi Health Center in 2021.

\begin{tabular}{|c|c|c|c|c|c|}
\hline \multirow[t]{2}{*}{ CHARACTERISTICS } & \multicolumn{2}{|c|}{$\begin{array}{c}\text { Malnutrition } \\
\text { (Case) }\end{array}$} & \multicolumn{2}{|c|}{$\begin{array}{l}\text { Good Nutrition } \\
\text { (Control) }\end{array}$} & \multirow[t]{2}{*}{$p$} \\
\hline & $n=38$ & $\%$ & $\mathbf{n}=\mathbf{3 8}$ & $\%$ & \\
\hline \multicolumn{6}{|l|}{ Age } \\
\hline $17-25$ years old & 5 & 13,2 & 2 & 9,2 & \multirow[t]{4}{*}{0,272} \\
\hline 26-35 years old & 14 & 36,8 & 22 & 47,4 & \\
\hline $36-45$ years old & 15 & 39.5 & 13 & 36,8 & \\
\hline$\geq 46$ years old & 4 & 10,5 & 1 & 6,6 & \\
\hline \multicolumn{6}{|l|}{ Education } \\
\hline Graduated Elementary & 11 & 28,9 & 14 & 36,8 & \multirow{6}{*}{0,456} \\
\hline School & 11 & 28,9 & 6 & 15,8 & \\
\hline Graduated Junior High & 13 & 34,3 & 12 & 31,6 & \\
\hline School & 3 & 7,9 & 6 & 15,8 & \\
\hline \multicolumn{5}{|l|}{ High School Graduation } & \\
\hline \multirow{2}{*}{\multicolumn{6}{|c|}{ Bachelor }} \\
\hline & & & & & \\
\hline Civil servant & 1 & 2,6 & 1 & 2,6 & \multirow[t]{4}{*}{0,804} \\
\hline Enterpreneur & 4 & 10,5 & 4 & 10,5 & \\
\hline Farmer & 3 & 7,9 & 6 & 15,8 & \\
\hline Housewife & 30 & 79 & 27 & 71,1 & \\
\hline \multicolumn{6}{|l|}{ Number of children } \\
\hline $1-2$ & 20 & 52,6 & 25 & 65,8 & \multirow[t]{2}{*}{0,194} \\
\hline$>3$ & 18 & 36,8 & 13 & 34,2 & \\
\hline
\end{tabular}

Table 1 shows that most of the age group of mothers with malnourished toddlers were in the age group of 36-45 years, amounting to 15 people $(39.5 \%)$ and the highest number of well-nourished children was at the age of 26-35 years, which were 22 people (47.4\%). The education of mothers with malnourished toddlers mostly graduated from high school (SLTA), who were 13 people (34.3\%) and the group of toddlers with good nutrition mostly graduated from elementary school (SD), which are 14 people $(36.8 \%)$. The work of mothers of toddlers who are malnourished and well-nourished are mostly housewives, that were 30 people $(71.1 \%)$. The number of children in mothers of 
toddlers with malnutrition and good nutrition is mostly 1-2 people. The results of statistical analysis with the Chi-Square Test showed no relationship between the influence of mother's age, education, occupation and number of children on the nutritional status of toddlers.

Table 2. Relationship between Toddler Characteristics and Toddler Nutritional Status in the working area of Feapoi Health Center in 2021.

\begin{tabular}{|c|c|c|c|c|c|c|c|c|}
\hline \multirow[t]{2}{*}{$\overline{\text { Category }}$} & \multicolumn{2}{|c|}{$\begin{array}{c}\text { Malnutritio } \\
\text { n (Case) }\end{array}$} & \multicolumn{2}{|c|}{$\begin{array}{c}\text { Good } \\
\text { Nutrition } \\
\text { (Control) }\end{array}$} & \multirow[t]{2}{*}{$p$} & \multirow[t]{2}{*}{ OR } & \multicolumn{2}{|c|}{$95 \%$ CI } \\
\hline & $\mathrm{n}$ & $\%$ & $\mathbf{n}$ & $\%$ & & & Lower & Upper \\
\hline \multicolumn{9}{|l|}{ Age } \\
\hline 1 year old & 10 & 26,3 & 11 & 28,9 & 0,587 & & & \\
\hline 2 years old & 10 & 26,3 & 6 & 15,8 & & & & \\
\hline 3 years old & 9 & 3,7 & 13 & 34,2 & & & & \\
\hline 4 years old & 9 & 23,7 & 7 & 18,4 & & & & \\
\hline$\geq 5$ years old & & & 1 & 2,7 & & & & \\
\hline \multicolumn{9}{|c|}{ LBW history } \\
\hline Yes & 11 & 28,9 & 2 & 5,3 & 0,06 & 7,333 & 1,500 & 35,857 \\
\hline No & 27 & 71,1 & 36 & 94,7 & & & & \\
\hline \multicolumn{9}{|c|}{$\begin{array}{l}\text { Exclusive } \\
\text { breastfeeding }\end{array}$} \\
\hline Yes & 12 & 31,6 & 33 & 86,8 & 0.000 & 14,30 & 4,469 & 45,753 \\
\hline No & 26 & 68,4 & 5 & 13,2 & & & & \\
\hline \multicolumn{9}{|l|}{$\begin{array}{l}\text { Infectious } \\
\text { Disease }\end{array}$} \\
\hline Yes & 22 & 57,9 & 16 & 42,1 & 0,126 & 1,891 & 0,760 & 4,700 \\
\hline No & 16 & 42,1 & 22 & 57,9 & & & & \\
\hline \multicolumn{9}{|l|}{ Knowledge } \\
\hline Low & 20 & 52,6 & 9 & 23,7 & 0,009 & 3,580 & 1,341 & 9,561 \\
\hline Good & 18 & 47,4 & 29 & 76,3 & & & & \\
\hline
\end{tabular}

\section{Treatment}

\begin{tabular}{lllllllll}
\hline Low & 27 & 71,1 & 12 & 31,6 & 0,001 & 5,318 & 1,997 & 14,163 \\
Good & 11 & 28,9 & 26 & 68,4 & & & & \\
\hline
\end{tabular}

Table 2 shows that the most malnourished toddlers were in the 1-and 2-years age group $(10 \%)$ while the good nutrition was at the age of 3 years $(34.2 \%)$. The history of LBW in the group of toddlers with less nutrition $(28.9 \%)$ was higher than that of wellnourished children $(5.3 \%)$. The group of toddlers who received exclusive breastfeeding was $31.6 \%$ and well-nourished toddlers $(86.8 \%)$ received exclusive breastfeeding. Undernourished toddlers who suffered from infectious diseases were $57.9 \%$ and toddlers with good nutritional status were $42.1 \%$. Immunization of both undernourished toddlers and both $100 \%$ received complete immunization. The results of statistical analysis used the Chi-Square Test for age and history of infectious diseases have no effect on the nutritional status of toddlers, while the history of LBW has an influence on the nutritional status of toddlers with a value of $=0.06$ with an OR of 7.333 , and there is an effect of exclusive breastfeeding on the nutritional status of toddlers with a value of $=0.000$ with an OR value of 14.300 .

Most of the knowledge of mothers with toddlers with malnutrition was poor, who were 20 people $(52.6 \%)$ and mothers with good nutrition toddlers mostly had good 
knowledge, who were 29 people $(76.3 \%)$. The results of statistical analysis with the Chi-Square Test with p value $=0.009$ and OR 3, 580, hence, there is an influence of knowledge on the nutritional status of toddlers. Mothers with malnourished toddlers, mostly did not take action to meet the nutritional needs of their toddlers, which are 27 people $(71.1 \%)$. Mothers of toddlers with good nutritional status took action to meet the nutritional needs of their toddlers well, who were 26 people $(68.4 \%)$. The results of statistical analysis with the Chi-Square Test, $\mathrm{p}$ value $=0.001$ and OR 5, 318, thus, there is an effect of mother's actions on the nutritional status of toddlers.

Table 3. Factors Influencing the Nutritional Status of Toddlers Simultaneously in the Work Area of the Feapoi Health Center in 2021.

\begin{tabular}{lrccccc}
\hline Variable & B & Wald & P value & OR & \multicolumn{2}{c}{ 95\%C.I Exp (B) } \\
& & & & & Lower & Upper \\
\hline LBW & $-2,220$ & 6,038 & 0,014 & 0,109 & 0,18 & 0,638 \\
Exclusive & $-2,767$ & 19,440 & 0,000 & 0,063 & 0,18 & 0,215 \\
breastfeeding & 1,384 & 12,260 & 0,000 & 3,991 & & \\
Constant & & & & & & \\
\hline
\end{tabular}

Based on the results of the logistic regression test using the Backward Stepwise method, the factors that influence the nutritional status of toddlers with a history of low birth weight $(\mathrm{p}=0.014)$, and getting exclusive breastfeeding $(\mathrm{p}=0.000)$. Toddlers with a history of low birth weight and not getting exclusive breastfeeding are protective of the nutritional status of under-nourished/bad children. the possibility that children who do not have LBW will increase their nutritional status by 9 times (1/0.109). And children who get exclusive breastfeeding will increase their good nutritional status by 16 times $(1 / 1,063)$.

\section{a. Relationship between mother's age and nutritional status of toddlers}

The highest maternal age for undernourished toddlers is in the age group of 3645 years and the most well-nourished toddlers are at the age of 25-35 years, who were 22 people. Based on the Chi-Square statistical test, there is no effect between age and nutritional status of toddlers. These results are in accordance with Setyaningsih's research 2014 that the majority of mothers are in the age range of 21-40 years or early adulthood. In this phase, the responsibility for caring for toddlers, including parenting in terms of nutrition, is a normal life stage experienced by a woman (Setyaningsih \& Agustini, 2014).

The results of this study explain that maternal age does not affect the nutritional status of toddlers. The reason is that mothers with early adulthood play an important role in the upbringing of their children, especially in providing good nutrition for their children. The arrangement of meeting the nutritional needs of each mother is different. It is influenced by other factors.

\section{b. Relationship between education and nutritional status of toddlers}

The education of mothers with toddlers' nutritional status is mostly high school graduates and mothers with good nutritional status are mostly elementary school graduates. The results of the analysis show that there is no significant relationship between mother's education and undernutrition under five. This result is supported by Lestari, (2016), which shows that there is no significant relationship between mother's education and toddler malnutrition. It is because mothers do not receive education about nutritional status in formal education. Mothers with low education can get 
information related to nutrition through informal education through health workers at maternal health unit, health center or hospitals with information packaging that is easy to absorb and understand without having to go to higher education (Lestari, 2016).

Another research result was conducted by Gusrianti, et al., 2019, who found that education had no effect on the nutritional status of toddlers. This study is not in accordance with research conducted by Ahsan, et al., in 2013, which explained that the level of education is very influential on the level of nutrition in toddlers. Mothers with low levels of education tend to have toddlers with less nutrition and even stunting (Ahsan, et al., 2017).

Research conducted by Talukder found that malnourished toddlers were found in mothers or fathers who had basic education (Talukder, 2017). More than half of malnourished children live with families with large family members and most of their parents have low educational background (Galgamuwa, et al., 2017).

The level of education can determine the nutritional status of toddlers. The higher the level of education affects the mother's mindset in making good and right decisions in determining the growth and development of her toddler. However, the results of the research stated that there was no effect between the level of education and the nutritional status of toddlers. Many factors can determine the nutritional status of toddlers.

\section{c. Relationship between parents' occupation and the nutritional status of toddlers}

The work of mothers of toddlers with poor and good nutritional status is mostly as housewives and fathers of toddlers are mostly farmers. The results of statistical analysis with the Chi-Square Test have no effect on the nutritional status of toddlers. The results of the study were supported by Gusrianti who explained that work status had no effect on the nutritional status of toddlers (Gusrianti, et al., 2019). This result is not in accordance with the research conducted by Ahsan, et al., (2017), which explains that mothers who work outside the home significantly have underweight toddlers (Ahsan, et al., 2017).

Families with more income are likely to be good or even excessive in meeting their food needs. On the contrary, families with limited income tend to be less likely to meet their food needs, especially to meet nutritional needs. However, this opinion contradicts the results of the research. It happened because families in the Feapoi health center area always received direct assistance from the government in the form of additional food, financial support for underprivileged families. Furthermore, the main commodity for Rote Ndao district is rice production which contributes to increasing income for the community, which of course affects the purchasing power of food needs.

\section{d. The relationship between the number of children and the nutritional status of toddlers}

The number of toddlers with poor and good nutritional status is mostly 1-2 people. The results of statistical analysis with the Chi-Square Test did not affect the number of children on the nutritional status of toddlers. This result is supported by Lestari in 2016, with statistical analysis showing that there is no significant relationship between the number of family members and malnutrition in toddlers. It is because there are families of toddlers with the composition of the number of productive family members working more, so that it will increase family income which causes the condition of children's nutritional status to be better (Lestari, 2016). 
This study is not in accordance with Ahsan, et al., (2017), who found that birth spacing has a significant relationship with toddler nutrition. The wider the child birth interval, the better the nutritional status of toddlers (Ahsan, et al., 2017). A large number of family members is believed to have sufficient resources to work so as to improve their economic status. It causes the child's health condition and nutritional status to be better.

\section{e. Relationship of LBW History with Toddler Nutritional Status}

The results showed that the history of LBW in the group of underweight children was higher than those with good nutritional status who had a history of LBW. Statistical analysis with Chi-Square Test for LBW history has an influence on the nutritional status of toddlers. The results of this study are in accordance with Minkhatulmaula, et al., in 2020, who found that most of the undernourished children had a history of low birth weight so that there was a relationship between low birth weight and the incidence of malnutrition in the Karangpawitan District. It happens because mothers of toddlers have low knowledge of nutrition during pregnancy so they tend to experience anemia in mothers during pregnancy (Minkhatulmaula, et al., 2020).

Research conducted by Rahman in 2016, explained that this study found a very strong positive relationship between LBW and malnutrition among children under the age of five in Bangladesh. Toddlers who have a history of LBW tend to experience underweight during their growth period compared to toddlers with normal birth weight. Birth weight is a determinant of the nutritional status of toddlers. Children with a history of LBW tend to experience infections such as diarrhea and lower respiratory tract infections and an increased risk of complications including sleep apnea, jaundice, anemia, chronic lung disorders, fatigue and loss of appetite (Rahman, et al., 2016).

Children were born with low birth weight in the working area of the Feapoi health center, Rote Ndao district. The condition will have the potential to become a child with less nutrition, even worse. Furthermore, poor nutrition in toddlers has an impact on decreasing the level of intelligence or IQ. Moreover, the resulting impact is an increase in the incidence of illness and even death. Those who are still able to survive due to permanent nutritional deficiency, the quality of life has a very low level and cannot be improved even though at the next age their nutritional needs have been met.

\section{f. Relationship of Exclusive Breastfeeding with Nutritional Status of Toddlers}

The results showed that one third of the number of toddlers with poor nutritional status received exclusive breastfeeding, while the majority of wellnourished children received exclusive breastfeeding. The results of statistical analysis using the Chi-Square Test for toddlers who receive exclusive breastfeeding have an influence relationship on the nutritional status of toddlers. In the group of undernourished toddlers who received exclusive breastfeeding, 31.6\% and well-nourished toddlers $(86.8 \%)$ received exclusive breastfeeding.

This result is in accordance with Lestari, in 2016, who analyzed the relationship between history of breastfeeding and under-nutrition under five years of age. Toddlers with a history of non-exclusive breastfeeding have a 4.34 times greater chance of experiencing malnutrition than toddlers with a history of exclusive breastfeeding (Lestari, 2016). 
This finding is in line with Purba, et al., in 2020, which explains that there is a significant relationship between the duration of exclusive breastfeeding and the nutritional status of toddlers, where babies who are exclusively breastfed tend to experience better nutritional status, and vice versa (Purba, et al., 2020).

Toddlers who are exclusively breastfed in the working area of Feapoi in health center are in good nutritional status compared to toddlers who are not exclusively breastfed. Exclusive breastfeeding provides immune substances to toddlers so that the toddler becomes less susceptible to disease. Healthy toddlers do not lose their appetite so that their nutritional status remains good.

\section{g. Relationship of Infectious Diseases with nutritional status of toddlers}

In undernourished toddlers, most of them suffered from infectious diseases in the last 6 months compared to toddlers with good nutritional status. The results of this study indicate that both toddlers with poor and good nutritional status have the same risk of getting infectious diseases such as ARI, diarrhea. Based on the Chi-Square test, it was found that there was no effect of infectious disease on the nutritional status of Toddlers in Feapoi Rote Ndao.

The results of this study are supported by research conducted by Rosliana, et al., in 2020, which explains that the percentage of children aged $12-24$ months at the Teratai maternal health unit in the work area of the Ciasem Health Center, Subang Regency, who are undernourished and not sick have a higher percentage than children who are malnourished and sick. The results of statistical analysis of the relationship between comorbidities and nutritional status stated that there was no relationship between comorbidities and nutritional status (Rosliana, et al., 2020).

This study was also supported by Lestari, in 2016 who found that the results of the analysis of the relationship between a history of infectious diseases and malnutrition in toddlers showed that there was no significant relationship between a history of infectious diseases and under-nutrition toddlers. It is because prevention efforts against cases of malnutrition have been performed well by families of toddlers, for instance by exclusive breastfeeding (Lestari, 2016).

This study is not in accordance with Ristanti's research in 2020, which found that there was a relationship between infectious diseases and nutritional status in toddlers in the work area of the Paal V Health Center Jambi City in 2020. The results showed that toddlers suffering from infectious diseases had a higher risk of 6.6 times having toddlers with less nutritional status when compared to respondents who have toddlers who do not suffer from infectious diseases (Ristanti, et al., 2020).

The relationship between malnutrition and infectious diseases depends on the magnitude of the impact caused by a number of infections on the nutritional status itself. Some examples of how infections can contribute to malnutrition such as digestive infections can cause diarrhea, HIV/AIDS, tuberculosis, and some other chronic infectious diseases can cause anemia and intestinal parasites can cause anemia.

\section{h. Relationship between Immunization and Nutritional Status of Toddlers}

The results of this study showed that all toddlers with poor or good nutritional status all received complete immunization. The results of statistical tests with ChiSquare showed that there was no effect of immunization on the nutritional status of toddlers. The results of the study are not in accordance with Gebre, et al., in 2019, which states that children who have not been fully immunized have a higher risk of being underweight compared to children who are fully immunized. Children who are not immunized can be at risk of many vaccine-preventable diseases such as diarrhea and 
respiratory infections, which can lead to depletion of nutrients from the body (Gebre, et al., 2019).

Sand's study 2018 also found vaccination status, which was often found to be significantly associated with acute malnutrition. Vaccination status and frequent infections were found to be significantly associated with severe acute malnutrition in Mithi city center hospital, Tharparkar district, Sindh province (Sand, et al., 2018).

Complete immunization has a significant relationship with malnutrition because immunization provides immune substances to toddlers so that these toddlers become less susceptible to disease. Healthy toddlers will not lose their appetite so that nutritional status remains good. However, in this study, there was no effect on the nutritional status of toddlers it is because all toddlers, both malnourished and well nourished, have received complete immunization. Malnutrition status in most toddlers is caused by other risk factors.

\section{i. The Relationship of Knowledge to the Nutritional Status of Toddlers}

The results of the study showed that the knowledge of mothers with malnourished toddlers was mostly sufficient and mothers of toddlers with good nutrition had good knowledge about nutrition. The results of statistical analysis with the Chi-Square Test showed the effect of knowledge on the nutritional status of toddlers. These results are in accordance with the research of Lestari in 2016, which found that mothers who had less knowledge about nutrition had children with poor nutritional status, and there was a significant relationship between mother's knowledge and nutritional status and values. Lack of knowledge about the nutrients needed by toddlers causes mothers to give nonnutritious food to their children.

Based on the results of Ristanti's, et al., in 2020 research, it shows that there is a relationship between knowledge and nutritional status of toddlers in the work area of Paal V Health Center Jambi City in 2020. Knowledge is a risk factor for the nutritional status of toddlers. This relationship occurs because mothers who have extensive knowledge of toddler nutrition understand the techniques to meet the nutritional needs of their children. Furthermore, mothers are able to provide nutritious food, so that toddlers will have a good nutritional status. Conversely, if the mother does not understand how to understand the nutritional needs of her child, the child's nutritional status will be less good (Ristanti, et al., 2020)

Knowledge is the result of learning to hear, see and do. Mothers who have gained knowledge about nutrition for toddlers are more aware of feeding arrangements for their children, thus, they can apply what they know. This knowledge can be obtained from health center staff, sharing experiences with others, electronic and mass media. Conversely, if the mother's knowledge about toddler nutrition is not enough, it will affect the menu settings for toddlers according to their needs.

When mothers know that nutritious food has a good impact on the growth and development of their children, it is likely that mothers will provide food that meets the needs of their children, both in quantity and quality. The better the mother's knowledge of toddlers' nutrition will be the basis for supporting the good nutritional status of her toddlers.

\section{j. The Relationship of Mother's Actions to the Nutritional Status of Toddlers}

The results of the study showed that most of the mothers with toddlers who were malnourished did not take action to provide balanced nutritional intake to their children. On the other hand, mothers who had toddlers with good nutritional status always 
regularly provided food with balanced nutrition to their children. The results of statistical analysis with The Chi-Square test were obtained that there was an effect of mother's actions on the nutritional status of toddlers affecting the nutritional status of toddlers such as from toddler factors such as a history of LBW.

The results of this study were supported by Tariq, et al., in 2018 who explained that toddlers were malnourished due to a lack of nutritional food intake including supplements such as vitamin A by parents to their children. It occurs due to lack of education, knowledge, and socioeconomic factors (Tariq, et al., 2018).

This research is in accordance with research conducted by Fadilah, et al., in 2017 in Yosowilangun Lor Village, Lumajang Regency, which shows that there is a relationship between maternal behavior regarding balanced nutrition and the nutritional status of children that most mothers have less behavior about balanced nutrition. Mother's behavior about balanced nutrition is getting less, hence, the child's nutritional status is getting lower (Fadila, et al., 2017)

One of the factors that affect the nutritional status of children is the mother's behavior in choosing and providing food. The low mother's behavior can be caused by a lack of mother's level of knowledge about balanced nutrition and lack of ability to apply it in daily life.

\section{k. The dominant factor influencing the nutritional status of toddlers simultaneously at the Feapoi Health Center, Rote Ndao Regency}

Based on the results of the logistic regression test using the Backward Stepwise method, the factors that influence the nutritional status weretoddlers with a history of low birth weight and do not receive exclusive breastfeeding. The results of the Yirga, et al., study 2019 found that the dominant factors affecting the nutritional status of toddlers in Euthopia were the child's weight at birth, the mother's body mass index, and marital status (Yirga et al., 2019). Reinbott and Jordan 2016, explained that the problem of malnutrition in Cambodia is due to the type of food given to toddlers that does not meet nutritional standards, only watery porridge is given. It occurs due to lack of knowledge possessed by caregivers or parents. To improve the nutritional status of toddlers, the Cambodian government provides education to mothers about the fulfillment of toddler nutrition (Reinbott \& Jordan, 2016).

Tette, et al., 2015, found that malnutrition in children who were in Princess Marie Louise Children's Hospital was due to inadequate antenatal care family income. To be able to overcome this problem, optimal antenatal care assistance is needed, especially meeting the nutritional needs of pregnant women so that they do not give birth to babies with low body weight (Tette et al., 2015). Lestari, 2016, describes that the most dominant factor in the occurrence of malnutrition in toddlers is inadequate food intake (Lestari, 2016).

There are many factors that cause malnutrition/poor nutrition. Low birth weight will have the opportunity to experience nervous system disorders, which will result in slow growth and development when compared to normal weight. Breast milk has a very complete nutritional content. If given exclusively, it will increase the body's resistance so that it can reduce the risk of illness.

\section{CONCLUSION}

Most mothers with malnourished toddlers are in adulthood, have high school education (SLTA), do not work, and the number of children in a family of 1-2 people, have less knowledge and actions in meeting the nutritional needs of their toddlers. Toddlers who do not get exclusive breastfeeding and low birth weight tend to have poor 
Aty, Y. M. V. B., Herwanti, E., \& Mochsen, R. (2021). Simultaneous Factors Affecting Toddler Nutritional Status. JURNAL INFO KESEHATAN, 19(1), 64-76. https://doi.org/10.31965/infokes.Vol19/ss1.514

75

nutritional status. These two conditions are simultaneous factors that cause malnutrition in toddlers in the Feapoi working area, Rote Ndao district. It is recommended for further research on health promotion efforts for pregnant women to reduce the risk of low birth weight (LBW) and increase exclusive breastfeeding.

\section{REFERENCES}

Ahsan, K. Z., Arifeen, S. E., Al-Mamun, M. A., Khan, S. H., \& Chakraborty, N. (2017). Effects of individual, household and community characteristics on child nutritional status in the slums of urban Bangladesh. Archives of Public Health, 75(1), 1-13. doi: https://doi.org/10.1186/s13690-017-0176-x

Boli, E. B., Baliwati, Y. F., \& Sukandar, D. (2018). Komitmen Politik dan Peluang Pengembangan Kebijakan Gizi Pemerintah Daerah Provinsi Nusa Tenggara Timur. Media Kesehatan Masyarakat Indonesia Universitas Hasanuddin, 14(4), 351-359. doi: http://dx.doi.org/10.30597/mkmi.v14i4.5104

Dinas Kesehatan Kabupaten Rote Ndao. (2019). Rencana Strategi Dinas Kesehatan Kabupaten Rote Ndao 2019-2024. Rote Ndao: Dinas Kesehatan Kabupaten Rote Ndao.

Fadila, R. N., Amareta, D. I., \& Febriyatna, A. (2017). Hubungan Pengetahuan Dan Perilaku Ibu Tentang Gizi Seimbang Dengan Status Gizi Anak Tk Di DesaYosowilangun Lor Kabupaten Lumajang. Jurnal Kesehatan, 5(1), 14-20. doi: https://doi.org/10.25047/j-kes.v5i1.26

Galgamuwa, L. S., Iddawela, D., Dharmaratne, S. D., \& Galgamuwa, G. L. S. (2017). Nutritional status and correlated socio-economic factors among preschool and school children in plantation communities, Sri Lanka. BMC Public Health, 17 (377). doi: https://doi.org/10.1186/s12889-017-4311-y

Gebre, A., Surender Reddy, P., Mulugeta, A., Sedik, Y., \& Kahssay, M. (2019). Prevalence of Malnutrition and Associated Factors among Under-Five Children in Pastoral Communities of Afar Regional State, Northeast Ethiopia: A CommunityBased Cross-Sectional Study. Journal of Nutrition and Metabolism, 2019 (9187609). doi: https://doi.org/10.1155/2019/9187609

Gusrianti, G., Azkha, N., \& Bachtiar, H. (2019). Analisis Faktor yang Berhubungan dengan Status Gizi Balita di Kelurahan Limau Manis Selatan Wilayah Kerja Puskesmas Pauh Kota Padang. Jurnal Kesehatan Andalas, 8(4), 109-114. doi: https://doi.org/10.25077/jka.v8i4.1126

Kementerian Kesehatan, R. I. (2018). Laporan Riskesdas 2018. Jakarta: Kementerian Kesehatan Republik Indonesia.

Kementerian Kesehatan, R. I. (2019). Gizi Seimbang, Prestasi Gemilang. Jakarta: Warta Kesmas.

Kementerian Kesehatan RI. (2019). Kemenkes Tingkatkan Status Gizi Masyarakat. Jakarta: Biro Komunikasi dan Pelayanan Masyarakat, Kementerian Kesehatan Republik Indonesia.

Kementerian Kesehatan, R. I. (2020). Profil Kesehatan Indonesia Tahun 2019. Jakarta: Kementerian Kesehatan Republik Indonesia.

Lestari, N. D. (2016). Analisis determinan gizi kurang pada balita di Kulon Progo, Yogyakarta. IJNP (Indonesian Journal of Nursing Practices), 1(1), 15-21.

Minkhatulmaula, M., Pibriyanti, K., \& Fathimah, F. (2020). Faktor Risiko Kejadian Gizi Kurang pada Balita di Etnis Sunda. Sport and Nutrition Journal, 2(2), 41-48.

Munthofiah, D. (2019). Hubungan Konsumsi Fast Food, Kebiasaan Dan Kualitas Sarapan Pagi Dengan Status Gizi Siswa Sd Muhammadiyah Program Khusus 
Surakarta. Skripsi. Institute Teknologi Sains dan Kesehatan, PKU Muhammadiyah Surakarta.

Purba, I. E., Purba, A., \& Sembiring, R. (2020). Factors associated with nutritional status of children under the age of 5 years in the working area of Sadabuan Public Health Center. Enfermería Clínica, 30, 140-143. doi: https://doi.org/10.1016/j.enfcli.2019.11.040

Rahman, M. S., Howlader, T., Masud, M. S., \& Rahman, M. L. (2016). Association of low-birth weight with malnutrition in children under five years in Bangladesh: do mother's education, socio-economic status, and birth interval matter?. PloS one, 11(6), e0157814. doi: https://doi.org/10.1371/journal.pone.0157814

Reinbott, A., \& Jordan, I. (2016). Determinants of child malnutrition and infant and young child feeding approaches in Cambodia. Hidden Hunger, 115, 61-67. doi: https://doi.org/10.1159/000444609

Ristanti, E., Harahap, P. S., \& Subakir, S. (2020). Faktor Yang Mempengaruhi Status Gizi Pada Balita Di Wilayah Kerja Puskesmas Paal V Kota Jambi. Journal Of Healthcare Technology and Medicine, 6(2), 742-753. doi: https://doi.org/10.33143/jhtm.v6i2.980

Rosliana, L., Widowati, R. \& Kurniati, D. (2020). Hubungan Pola Asuh, Penyakit Penyerta, Dan Pengetahuan Ibu Dengan Status Gizi Pada Anak Usia 12-24 Bulan Di Posyandu Teratai Wilayah Kerja Puskesmas Ciasem Kabupaten Subang Tahun 2020. Syntax Idea, 2(8), 415-428.

Sand, A., Kumar, R., Shaikh, B. T., Somrongthong, R., Hafeez, A., \& Rai, D. (2018). Determinants of severe acute malnutrition among children under five years in a rural remote setting: A hospital based study from district Tharparkar-Sindh, Pakistan. Pakistan Journal of Medical Sciences, 34(2), 260-265. doi: https://doi.org/10.12669/pjms.342.14977

Setyaningsih, S. R., \& Agustini, N. (2014). Pengetahuan, Sikap, dan Perilaku Ibu dalam Pemenuhan Gizi Balita: Sebuah Survei. Jurnal Keperawatan Indonesia, 17(3), 8894. doi: https://doi.org/10.7454/jki.v17i3.451

Talukder, A. (2017). Factors associated with malnutrition among under-five children: illustration using Bangladesh demographic and health survey, 2014 data. Children, 4(10), 88. doi: https://doi.org/10.3390/children4100088

Tariq, J., Sajjad, A., Zakar, R., Zakar, M. Z., \& Fischer, F. (2018). Factors associated with undernutrition in children under the age of two years: secondary data analysis based on the Pakistan demographic and health survey 20122013. Nutrients, 10(6), 676. doi: https://doi.org/10.3390/nu10060676

Tette, E. M., Sifah, E. K., \& Nartey, E. T. (2015). Factors affecting malnutrition in children and the uptake of interventions to prevent the condition. $B M C$ pediatrics, 15(1), 1-11.doi: https://doi.org/10.1186/s12887-015-0496-3

Yirga, A. A., Mwambi, H. G., Ayele, D. G., \& Melesse, S. F. (2019). Factors affecting child malnutrition in Ethiopia. African health sciences, 19(2), 1897-1909. doi: https://doi.org/10.4314/ahs.v19i2.13 